\title{
CHALLENGES OF ONLINE TEACHING DURING THE COVID-19 PANDEMIC
}

\author{
Martina Malogorski Jurjević \\ Elementary school Jordanovac, Croatia \\ Marina Đuranović \\ University of Zagreb, Faculty of Teacher Education, Croatia \\ Diana Olčar \\ University of Zagreb, Faculty of Teacher Education, Croatia
}

\begin{abstract}
The teaching profession has always been complex and dynamic, but now the challenges are posed to a society as a whole by the COVID-19 pandemic. The purpose of the research was to determine teachers' perceptions of the challenges of conducting online teaching during the COVID-19 pandemic. 413 teachers from Croatia participated in the research. Respondents were distributed according to the level of education at which they work in three groups (primary school teachers - grades $1^{\text {st }}$ to $4^{\text {th }}$, subject teachers - grades $5^{\text {th }}$ to $8^{\text {th }}$ of primary school, subject teachers - secondary school). According to the results of the research, teachers estimated that difficulties in online teaching generally occur occasionally. There were statistically significant differences in some of the items in the perception of the challenges in online teaching among teachers depending on the level of education at which they work. Still, in general, teachers at all three levels of education experienced approximately the same amount of challenges. More challenges in online teaching have been related to a higher level of burnout and correlated positively with higher numbers of students to teach. Age has been unrelated to challenges in online teaching. Since difficulties in conducting online teaching hinder the educational process, this research could serve as an indicator of problems and an initial step to solving them.
\end{abstract}

Keywords: burnout, JD-R model, online teaching, pandemic, teachers.

\section{Introduction}

The vocation of a teacher is one of the most complex ones. Teachers are expected to participate in the implementation of educational reforms and the creation of the subject curriculum, continuously improve and prepare for teaching, keep up administrative records, and adapt teaching methods to new generations of students growing up in a time of highly developed technology (Chang, 2009; Jurčić, 2014; Miljković, Đuranović, \& Vidić, 2019). Furthermore, teachers are expected to create a stimulating classroom environment that will enable the 
growth and development of each student (Durrant, 2010; Klasnić, Đuranović \& Maras, 2018). The teacher should teach students to learn, think critically, solve problems, encourage their creativity, help them develop social and communication skills, train them for teamwork, and for humane and responsible behaviour (Jurčić, 2014). Continuous monitoring and evaluation of students is also one of the tasks of teachers. In addition to the above, the teacher should cooperate in their work with the principal and the professional service of the school. The teacher is expected to motivate parents to be actively involved in the life and work of the school and to build a partnership with them (Epstein, 2001; Ljubetić \& Zadro, 2009; Maleš, 2015; Zrilić \& Marin, 2019).

It is evident that teaching is challenging, but it became even more difficult in 2020 when an epidemic caused by the SARS-CoV-2 virus has spread all over the world. The pandemic caused considerable changes in everyday functioning, in almost every domain of peoples' lives. For the educational system this meant that the schools have closed and real classrooms were replaced by virtual ones. Distance education has a long history dating back to the 18th century. There are numerous definitions of distance learning in the literature, but it is most often defined as an approach to learning in which the teacher and the student are in different environments, i.e. they are physically distant and therefore communicate using technology (Batarelo Kokić, 2020; Guilar \& Loring, 2008; Matijević, 2000). Distance learning is nothing new, but in the case when it completely, suddenly and unexpectedly replaces real classroom teaching, it is surely challenging for teachers. It requires teachers to use new and different methods and procedures, new forms of communication with students, new ways of monitoring, evaluating and assessing them and to use different (and unknown) tools.

Studies prove that teaching is a stressful profession (Kyriacou, 2001; Olčar, 2015) and prolonged stress can lead to burnout. Burnout is a state of exhaustion in which one is cynical about the value of one's occupation and doubtful of one's capacity to perform (Maslach \& Jackson, 1986). Burnout syndrome is characterrized by high exhaustion and low engagement towards work (Demerouti, Bakker, Vardakou, \& Kantas, 2003). According to job-demands and resources (J-DR) model (Schaufeli \& Taris, 2014) the more challenges the person is exposed to at work, the higher is the possibility of burnout. Burnout can affect teachers' success in teaching, career decision-making, physical and mental health, and job satisfaction (Jepson \& Forrest, 2006) so it is necessary to prevent it by lowering the exposure to stressors. The occurrence of stress is determined by factors such as workload, work role, working conditions, autonomy at work, cooperation with students and parents, support from colleagues and administration, and working and organizational conditions (Schaufeli \& Taris, 2014). Working at different educational levels and with students of different age, can create various challenges for teachers. For example, research with teachers in England found that primary 
school teachers were more exposed to negative parental behaviour and high school teachers were more exposed to poor student behaviour (Ravalier \& Walsh, 2018). Therefore, one of the aims of this research was to find the differences in challenges that teachers are facing given the level of education at which they work.

The research of teachers' adjustment during the pandemic is lacking and still being made. Still, one very recent research on a sample of 1266 Croatian primary school teachers (Sablić, Klasnić \& Škugor, 2020) showed that teachers state that they spend much more time preparing for online classes than when working with students in the classroom and that it is difficult to draw the line between working and free time. Furthermore, study showed that teaches invested a lot of time in researching and testing new technologies. They were more satisfied with the support of the school principal than with the support of the Ministry of Science and Education. As the times we live in are unprecedented, it is important to examine the teachers' adaptation so that we are able to give teachers adequate support if it is needed.

Therefore, this paper seeks to answer the following problems:

1. Determine the teachers' perception of the challenges of conducting online classes during the COVID-19 pandemic.

2. Examine the differences in the teachers' perception of the challenges of online teaching depending on the level at which they teach.

3. As these are unprecedented times and the first time online teaching is happening to this extent, the hypotheses for the first two problems were not proposed.

4. Examine the relationship between the challenges in online teaching and teacher burnout, age, years of service and the number of students.

Hypothesis 1 - The teachers who experience more challenges in online teaching will also experience higher exhaustion and lower engagement.

Hypothesis 2 - More challenges in online teaching will be experienced by older teachers and teachers with more students.

\section{Methodology}

\section{Participants}

Teachers from all parts of Croatia $(\mathrm{N}=413)$ participated in the research. The participants were mostly female (94\%). The mean age of participants was 43.91 years $(S D=9.46$; range $=24-65$ years $)$ and on the average, they had been teaching for around 18 years $(M=17.89$; $S D=9.96$; range $=1-43$ years $)$. On the average, they had around 104 students $(S D=90.45)$, with a range from 3 to 680 students. For the purpose of this research the participants were divided in three groups according to the level of education at which they worked as it is presented in Table 1. 
Table 1 Distribution of Respondents According to Workplace

\begin{tabular}{l|c|c}
\hline Teachers according to the level of education at which they work & $\mathrm{N}$ & Percent \\
\hline $\begin{array}{l}\text { 1. Lower grades primary school teachers (LGPST }- \text { grades } 1^{\text {st }} \text { to } 4^{\text {th }} \text { ) } \\
- \text { one class teacher for all subjects }\end{array}$ & 121 & $29.3 \%$ \\
\hline $\begin{array}{l}\text { 2. Higher grades primary school teachers }(H G P S T \\
\left.8^{\text {th }}\right)- \text { grades } 5^{\text {th }} \text { to }\end{array}$ & 186 & $45 \%$ \\
\hline $\begin{array}{l}\text { 3. Secondary school teachers }\left(S S T-\text { grades } 9^{\text {th }} \text { to } 12^{\text {th }}\right)-\text { different } \\
\text { subject teacher for each subject }\end{array}$ & 106 & $25.7 \%$ \\
\hline Total & 413 & $100 \%$ \\
\hline
\end{tabular}

Procedure

The research was conducted in August 2020. Online surveys were sent to teachers in the Republic of Croatia via the Facebook social network. The purpose of the research was explained at the beginning of the questionnaire. By filling in the survey the participants agreed to be a part of the research. It took the respondents an average of 15 minutes to complete the questionnaire. The participants were anonymous.

Instruments

For the purpose of the research, a questionnaire for measuring challenges during online teaching was constructed based on previous literature about the stress in teaching (Kyriacou, 2001; Schaufeli \& Taris, 2014), the relevant literature on online teaching during the COVID-19 pandemic (e.g. Rasmitadila et al., 2020; Sablić et al., 2020; Sokal, Eblie Trudel \& Babb, 2020) as well as authors' interviews with teachers during June 2020. The questionnaire consisted of 18 statements which participants had to asses if and to which extent they represented a challenge for them during online teaching. A five-point Likert-type scale was used to assess teachers" perceptions (" 1 -"Not at all difficulty for me" to " 5 - A great difficulty for me"). Crombach $\alpha$ for a scale was $\alpha=.88$.

Oldenburg Burnout Inventory (Demerouti et al., 2003) measured the burnout on a two dimensional scale. The scale included 16 items; half of them worded positively, half worded negatively. Items were assessed on a four point Lickert type scale ("1 - Strongly agree” to “4 - Strongly disagree”). In our study, after four items were removed from the analysis, the PCA factor analysis loaded two factors: engagement (e.g. "I always find new and interesting aspects in my work", $\alpha=.75$ ) and exhaustion (e.g. "After my work, I usually feel worn out and weary.", $\alpha=.86)$.

\section{Results and Discussion}

In table 2 teachers' perceptions of the source of difficulties in conducting online teaching on 18 items according to the level of education at which the 
teachers work are presented. The mean value for all items for all three groups of teachers was $M=2.95(S D=1.28)$. Furthermore, the means for all items, for all three groups of teachers, were estimated between 2.06 and 4.04. Since the higher value represented a higher assessment of the difficulty, it seems that difficulties existed, but that they mostly occurred occasionally. Therefore, it can be concluded that teachers competently and successfully overcame the initial challenges.

Table 2 Descriptive Statistics, One-way ANOVA and Scheffe Tests (N=413)

\begin{tabular}{|c|c|c|c|c|c|c|c|}
\hline & & $\begin{array}{l}\text { (grades } \\
\left.1^{\text {st }}-4^{\text {th }}\right)\end{array}$ & $\begin{array}{l}\text { (grades } \\
\left.5^{\text {th }}-8^{\text {th }}\right)\end{array}$ & $\begin{array}{l}\text { Secondary } \\
\text { sch. } \\
{\text { (grades } 9^{\text {th }}}^{-12^{\text {th }} \text { ) }} \\
\end{array}$ & & & \\
\hline & $\begin{array}{c}\mathrm{M} \\
(\mathrm{SD})\end{array}$ & $\begin{array}{c}\mathrm{M} \\
(\mathrm{SD}) \\
\end{array}$ & $\begin{array}{c}\mathrm{M} \\
(\mathrm{SD})\end{array}$ & $\begin{array}{c}\mathrm{M} \\
(\mathrm{SD}) \\
\end{array}$ & $\begin{array}{c}\mathrm{F} \\
(2,401)\end{array}$ & $\mathrm{p}$ & Scheffe \\
\hline $\begin{array}{l}\text { Working conditions at } \\
\text { home. }\end{array}$ & $\begin{array}{c}2.56 \\
(1.21)\end{array}$ & $\begin{array}{l}2.66 \\
(1.14)\end{array}$ & $\begin{array}{c}2.45 \\
(1.23)\end{array}$ & $\begin{array}{c}2.64 \\
(1.22)\end{array}$ & & & \\
\hline Technical difficulties. & $\begin{array}{c}2.54 \\
(1.15)\end{array}$ & $\begin{array}{c}2.78 \\
(1.21)\end{array}$ & $\begin{array}{c}2.46 \\
(1.16)\end{array}$ & $\begin{array}{c}2.44 \\
(1.01)\end{array}$ & & & \\
\hline $\begin{array}{l}\text { Lack of digital } \\
\text { competencies. }\end{array}$ & $\begin{array}{c}2.24 \\
(1.15)\end{array}$ & $\begin{array}{c}2.60 \\
(1.23)\end{array}$ & $\begin{array}{l}2.10 \\
(1.07)\end{array}$ & $\begin{array}{l}2.06 \\
(1.10)\end{array}$ & 8.92 & .00 & $1>2,3$ \\
\hline $\begin{array}{l}\text { Preparation of } \\
\text { activities. }\end{array}$ & $\begin{array}{c}2.75 \\
(1.19)\end{array}$ & $\begin{array}{c}2.63 \\
(1.20)\end{array}$ & $\begin{array}{c}2.77 \\
(1.13)\end{array}$ & $\begin{array}{c}2.85 \\
(1.26)\end{array}$ & 1.01 & .37 & \\
\hline Correcting tasks. & $\begin{array}{c}3.38 \\
(1.29)\end{array}$ & $\begin{array}{l}2.97 \\
(1.31)\end{array}$ & $\begin{array}{c}3.49 \\
(1.26)\end{array}$ & $\begin{array}{c}3.65 \\
(1.23)\end{array}$ & 9.29 & .00 & $1<2,3$ \\
\hline $\begin{array}{l}\text { Monitoring students' } \\
\text { progress. }\end{array}$ & $\begin{array}{c}3.38 \\
(1.32)\end{array}$ & $\begin{array}{l}3.14 \\
(1.38)\end{array}$ & $\begin{array}{c}3.43 \\
(1.32)\end{array}$ & $\begin{array}{c}3.54 \\
(1.23)\end{array}$ & 2.96 & .05 & \\
\hline $\begin{array}{l}\text { Communication and } \\
\text { interaction with } \\
\text { students. }\end{array}$ & $\begin{array}{c}2.97 \\
(1.33)\end{array}$ & $\begin{array}{c}2.80 \\
(1.44)\end{array}$ & $\begin{array}{c}3.06 \\
(1.29)\end{array}$ & $\begin{array}{c}2.99 \\
(1.24)\end{array}$ & 1.39 & .25 & \\
\hline $\begin{array}{l}\text { Lack of feedback from } \\
\text { students }\end{array}$ & $\begin{array}{c}3.53 \\
(1.24)\end{array}$ & $\begin{array}{c}3.32 \\
(1.38)\end{array}$ & $\begin{array}{c}3.59 \\
(1.16)\end{array}$ & $\begin{array}{c}3.69 \\
(1.20)\end{array}$ & 2.69 & .07 & \\
\hline Cheating by students. & $\begin{array}{c}3.54 \\
(1.28)\end{array}$ & $\begin{array}{l}3.05 \\
(1.36)\end{array}$ & $\begin{array}{c}3.73 \\
(1.17)\end{array}$ & $\begin{array}{c}3.83 \\
(1.19)\end{array}$ & 14.19 & .00 & $1<2,3$ \\
\hline $\begin{array}{l}\text { Lack of support from } \\
\text { school management. }\end{array}$ & $\begin{array}{c}2.58 \\
(1.34)\end{array}$ & $\begin{array}{l}2.58 \\
(1.27)\end{array}$ & $\begin{array}{l}2.60 \\
(1.39)\end{array}$ & $\begin{array}{c}2.59 \\
(1.33)\end{array}$ & 0.00 & .99 & \\
\hline $\begin{array}{l}\text { Lack of support from } \\
\text { the Ministry of } \\
\text { Education. }\end{array}$ & $\begin{array}{c}3.37 \\
(1.32)\end{array}$ & $\begin{array}{c}3.35 \\
(1.28)\end{array}$ & $\begin{array}{c}3.37 \\
(1.36)\end{array}$ & $\begin{array}{c}3.37 \\
(1.31)\end{array}$ & 0.01 & .99 & \\
\hline $\begin{array}{l}\text { School leadership } \\
\text { pressures. }\end{array}$ & $\begin{array}{c}2.20 \\
(1.32)\end{array}$ & $\begin{array}{l}2.15 \\
(1.17)\end{array}$ & $\begin{array}{l}2.28 \\
(1.39)\end{array}$ & $\begin{array}{c}2.15 \\
(1.35)\end{array}$ & 0.44 & .64 & \\
\hline $\begin{array}{l}\text { Lack of parental } \\
\text { support. }\end{array}$ & $\begin{array}{c}2.50 \\
(1.94)\end{array}$ & $\begin{array}{c}2.24 \\
(1.15)\end{array}$ & $\begin{array}{c}2.66 \\
(1.19)\end{array}$ & $\begin{array}{c}2.57 \\
(1.23)\end{array}$ & 4.64 & .01 & $1<2$ \\
\hline $\begin{array}{l}\text { Parental interference in } \\
\text { my work. }\end{array}$ & $\begin{array}{c}2.39 \\
(1.31)\end{array}$ & $\begin{array}{c}2.31 \\
(1.21)\end{array}$ & $\begin{array}{c}2.57 \\
(1.39)\end{array}$ & $\begin{array}{c}2.14 \\
(1.24)\end{array}$ & 3.85 & .02 & $2>3$ \\
\hline
\end{tabular}


Malogorski Jurjević et al., 2021. Challenges of Online Teaching During the COVID-19 Pandemic

\begin{tabular}{|c|c|c|c|c|c|c|c|}
\hline $\begin{array}{l}\text { Lack of social } \\
\text { interaction with } \\
\text { colleagues. }\end{array}$ & $\begin{array}{c}3.07 \\
(1.30)\end{array}$ & $\begin{array}{c}3.09 \\
(1.29)\end{array}$ & $\begin{array}{c}3.20 \\
(1.35)\end{array}$ & $\begin{array}{c}2.83 \\
(1.25)\end{array}$ & 2.78 & .06 & \\
\hline $\begin{array}{l}\text { A large number of } \\
\text { students I teach. }\end{array}$ & $\begin{array}{c}3.02 \\
(1.49)\end{array}$ & $\begin{array}{c}2.36 \\
(1.35)\end{array}$ & $\begin{array}{c}3.22 \\
(1.45)\end{array}$ & $\begin{array}{c}3.36 \\
(1.46)\end{array}$ & 17.65 & .00 & $1<2,3$ \\
\hline $\begin{array}{l}\text { Difficulties in } \\
\text { organizing working } \\
\text { hours. }\end{array}$ & $\begin{array}{c}3.22 \\
(1.42)\end{array}$ & $\begin{array}{c}3.05 \\
(1.39)\end{array}$ & $\begin{array}{c}3.25 \\
(1.41)\end{array}$ & $\begin{array}{c}3.33 \\
(1.44)\end{array}$ & 1.22 & .30 & \\
\hline $\begin{array}{l}\text { Lack of recognition of } \\
\text { teacher work / effort. }\end{array}$ & $\begin{array}{c}3.79 \\
(1.27)\end{array}$ & $\begin{array}{c}3.51 \\
(1.33)\end{array}$ & $\begin{array}{c}3.82 \\
(1.32)\end{array}$ & $\begin{array}{c}4.04 \\
(1.06)\end{array}$ & 5.04 & .01 & $1<3$ \\
\hline Total & $\begin{array}{c}2.95 \\
(1.28)\end{array}$ & $\begin{array}{c}2.81 \\
(0.74)\end{array}$ & $\begin{array}{c}3.00 \\
(0.74)\end{array}$ & $\begin{array}{c}3.00 \\
(0.70)\end{array}$ & 2.94 & .05 & \\
\hline Burnout - Engagement & $\begin{array}{c}3.11 \\
(0.52) \\
\end{array}$ & $\begin{array}{c}3.21 \\
(0.46) \\
\end{array}$ & $\begin{array}{c}3.07 \\
(0.55) \\
\end{array}$ & $\begin{array}{c}3.06 \\
(0.53) \\
\end{array}$ & 3.16 & .04 & $1>2,3$ \\
\hline Burnout - Exhaustion & $\begin{array}{c}2.89 \\
(0.70)\end{array}$ & $\begin{array}{c}2.88 \\
(0.71)\end{array}$ & $\begin{array}{c}2.90 \\
(0.70)\end{array}$ & $\begin{array}{c}2.90 \\
(0.73)\end{array}$ & 0.03 & .97 & \\
\hline
\end{tabular}

The last item, "Lack of recognition of teacher work/ effort" ( $M=3.79$; $S D=1.27$ ), has the highest mean for all three categories of respondents. That indicates that teachers, no matter at which level of education they work, feel not recognized and appreciated for their engagement. This finding is consistent with previous studies which also state that one of the sources of stress at work is lack of recognition (Brun \& Dugas, 2008; Maphalala, 2014). Other considerable stressors were: correcting tasks $(M=3.38 ; S D=1.29)$, monitoring students' progress $(M=3.38 ; S D=1.32)$, lack of feedback from students $(M=3.53$; $S D=1.24)$, lack of support from the Ministry of Education $(M=3.37 ; S D=1.32)$, lack of social interaction with colleagues $(M=3.07 ; S D=1.30)$, a large number of students to teach $(M=3.02 ; S D=1.49)$ and difficulties in organizing working hours $(M=3.22 ; S D=1.27)$. Item "School leadership pressures (principal and pedagogical support staff)" has the lowest general mean $(M=2.20$; $S D=1.32)$, so it can be concluded that school leadership was supportive towards teachers during distance learning.

Finally, ANOVA showed that in general all three groups of teachers show the same perceived amount of challenges due to online teaching $(F=2.94$; $p=0.05$ ). Previous studies showed that stress and burnout are related to working conditions (Ravalier \& Walsh, 2018; Schaufeli \& Taris, 2014), nevertheless, the small differences in working conditions with students at different levels of education and with students of different age at the end obviously sum up to the same level of challenges.

The one-way ANOVA and Scheffe tests were used to find if there are statistically significant differences in the perception of the source of difficulties among teachers depending on the level of education at which they work. Lower grades primary school teachers (LGPST) reported having more difficulties with 
technical problems $(F=3.43 ; p=0.03)$ and lack of digital competencies $(F=8.92 ; p<0.01)$ than higher grades primary school teachers (HGPST) and secondary school teachers (SST). LGPST work with ages 7 to 10/11 so the biggest challenge for them was that students were not being accustomed to working with digital technology. On the other hand, subject teachers, both working in primary (HGPST) and secondary school (SST), reported having more problems with correcting tasks $(F=9.29 ; p<0.01)$, cheating by students $(F=14.19 ; p<0.01)$, and having a large number of students they teach $(F=17.65 ; p<0.01)$ than class teachers - LGPST. All these results are expected. Cheating is more prevalent as students are older and stakes are higher (Davis, Drinan, \& Gallant, 2009) and subject teachers teach one subject in many classes so they have many students and therefore more students' assignments to correct and mark.

There was a statistically significant difference in the perception of parental support $(F=4.64 ; p<0.01$ ) between teachers of lower grades and higher grades of primary school. The transition to the $5^{\text {th }}$ grade, when each subject is taught by another subject teacher, can be quite a problem for the students, and additional parental involvement is needed to make the transition as easy as possible. Unfortunately, some parents feel that their children are old enough to overcome these difficulties on their own and do not provide them with sufficient support which is clearly showed in these results. On the other side, HGPST in comparison to SST struggled with parental interference in their work $(F=3.85 ; p=0.02)$. Parents of students in higher grades of primary school are worried whether the marks of their children will be good enough to ensure them opportunity to enrol in the preferred secondary school so they can try to pressure teachers to give better marks to their children. SST perceived more than LGPST that there was a lack of recognition for their work. In higher grades parents are more stressed about their children's marks so they may have more strained relationship with teachers, which can be perceived by teachers as lack of recognition for their effort.

According to the J-DR model (Schaufeli, \& Taris, 2014) it was expected that the more challenges teachers experience in the online learning, the more burnt out they will be, which is operationalized as greater exhaustion and lower engagement. As it can be seen in Table 3, this hypothesis was confirmed. A teaching is a stressful profession (Kyriacou, 2001), especially during pandemic, when conditions for teaching are constantly changing. However, from Table 2 it can be seen that teachers were doing relatively well. Their level of exhaustion was not too high $(\mathrm{M}=2.89$; $\mathrm{SD}=0.70)$ and their level of engagement was somewhat higher $(\mathrm{M}=3.11$; $\mathrm{SD}=0.52)$. These findings are in line with previous findings which show that, although teaching is a stressful profession, the teachers are still resilient to stress and engaged in their work (Brkić \& Rijavec, 2011; Olčar, 2015). 
Malogorski Jurjević et al., 2021. Challenges of Online Teaching During the COVID-19 Pandemic

Table 3 Descriptives and Correlation Table

\begin{tabular}{lccccc}
\hline & Engagement & Exhaustion & Age & $\begin{array}{c}\text { Years } \\
\text { working }\end{array}$ & $\begin{array}{c}\text { No. of } \\
\text { students }\end{array}$ \\
\hline $\begin{array}{l}\text { Challenges in online } \\
\text { learning }\end{array}$ & $-.19^{* *}$ & $.47^{* *}$ & -.07 & -.02 & $.12^{*}$ \\
\hline Engagement & & $-.28^{* *}$ & -.05 & -.02 & -.09 \\
\hline Exhaustion & & $.11^{*}$ & $.11^{*}$ & $.10^{*}$ \\
\hline Age & & & $.89^{* *}$ & -.02 \\
\hline Years working & & & & -.09 \\
\hline Mean (SD) & $3.11(0.52)$ & $2.89(0.7)$ & $43.91(9.46)$ & $17.89(9.96)$ & $104(90.45)$ \\
\hline Range & $1-4$ & $1-4$ & $24-65$ & $1-43$ & $3-680$ \\
\hline \multicolumn{1}{c}{ Note. ${ }^{* *} \mathrm{p}<0.01 ;{ }^{*} \mathrm{p}<0.05$} & & & &
\end{tabular}

It was also shown that perception of challenges in online learning was not related to teachers' age and length of service, only to the number of students $(\mathrm{r}=.124 ; \mathrm{p}<.05)$. Obviously Croatian teachers were well prepared for teaching online, but still the realistic challenges like the high number of students were present, probably because of higher workload that comes with higher numbers of students to teach. Pre-training in the use of ICT has shown to be an important determinant of perceived competence in the use of ICT (Krajnc, Huskić, Kokol \& Košir, 2020). As teachers less competent in the use of ICT showed greater levels of stress related to online teaching (Krajnc et al., 2020), it can be concluded that in Croatia younger and older teachers are relatively equally well prepared for online teaching. It is also possible that younger teachers are better skilled at ICT and older teachers have better skills needed for teaching itself, which in the end puts all teachers in a relatively similar position.

\section{Conclusion}

Online education is a specific way of conducting teaching and learning. In the pandemic conditions, it has become an unavoidable part of the teachers' job. In this study, teachers estimated that difficulties during online teaching generally occur occasionally. This is encouraging information given the large amount of changes in the organization of teaching that have occurred in a very short time. Depending on the level of education that the teachers are working at, there were small differences in the perception of difficulties. Still, on average all three groups of teachers showed the same perceived amount of challenges due to online teaching, regardless of the educational level that they teach. The biggest challenge for all groups of teachers was lack of recognition of teachers' work/ effort, which 
is, in our opinion, easily avoidable even without imposing substantial financial burden on schools' or states' budget.

This study has shown an average level of teachers' burnout. Burnout levels correlated positively with the number of challenges and higher number of students and it was not related to the teachers' age. We can conclude that Croatian teachers have showed to cope well with the challenges of online teaching regardless of their age.

Since the difficulties related to conducting online teaching hinder the educational process, this research could serve as an indicator of problems and an initial step to solving them in order to strengthen the teacher and student competencies.

\section{References}

Batarelo Kokić, I. (2020). Učim od kuće: školovanje u vrijeme pandemije COVID-19 bolesti. U V. Strugar, A. Kolak \& I. Markić (Eds.), Školovanje od kuće i nastava na daljinu u vrijeme HR-COVID-19 (pp. 7-25). Zagreb-Bjelovar: Hrvatska akademija znanosti i umjetnosti Zavod za znanstvenoistraživački i umjetnički rad u Bjelovaru; Hrvatsko pedagogijsko društvo; Element.

Brkić, I., \& Rijavec, M. (2011). Izvori stresa, suočavanje sa stresom i životno zadovoljstvo učitelja razredne i predmetne nastave. Napredak: časopis za pedagogijsku teoriju i praksu, 152(2), 211-225.

Brun, J.P., \& Dugas, N. (2008). An analysis of employee recognition: Perspectives on human resources practices. The International Journal of Human Resource Management, 19(4), 716-730.

Chang, M.L. (2009). An appraisal perspective of teacher burnout: Examining the emotional work of teachers. Educational Psychology Review, 21(3), 193-218.

Davis, S.F., Drinan, P.F., \& Gallant, T.B. (2009). Cheating in School: what we know and what we can do. Chichester, U.K. Wiley-Blackwell. doi:10.1002/9781444310252

Demerouti, E., Bakker, A.B., Vardakou, I., \& Kantas, A. (2003). The convergent validity of two burnout instruments: A multitrait-multimethod analysis. European Journal of Psychological Assessment, 19(1), 12-23.

Durrant, J.E. (2010). Positive Discipline in Everyday Teaching: Guidelines for Educators. Sweden: Save the Children.

Epstein, J.L. (2001). School, family, and community partnerships - Caring for the children we share. In J.L. Epstein (Ed.), School, family, and community partnerships: Preparing educa-tors and improving schools (pp. 403-426). Boulder, CO: Westview.

Guilar, J., \& Loring, A. (2008). Dialogue and Community in Online Learning: Lessons from Royal Roads University. Journal of Distance Education, 22(3), 19-40.

Jepson, E., \& Forrest, S. (2006). Individual contributory factors in teacher stress: The role of achievement striving and occupational commitment. British Journal of Educational Psychology, 76, 183-197.

Jurčić, M. (2014). Kompetentnost nastavnika - pedagoške i didaktičke dimenzije. Pedagogijska istraživanja, 11(1), 77-91.

Klasnić, I., Đuranović, M. \& Maras, N. (2018). Effective school discipline - the precondition for successful teaching. Society. Integration.Education proceedings of the International 
Scientific Conference. (pp. 229-239). Rezekne: Rezekne Academy of Technologies. DOI: 10.17770/sie2018vol1.3125

Krajnc, Ž., Huskić, A., Kokol, Z., \& Košir, K. (2020). Učenje in poučevanje na daljavo med zaprtjem šol zaradi epidemije COVID-19: Perspektiva pedagoških delavcev v osnovnih in srednjih šolah v prvem mesecu pouka na daljavo. In Ž. Lep \& K. Hacin Beyazoglu (Eds.), Psihologija pandemije: posamezniki in druŽba v žasu koronske krize (pp. 179189). Ljubljana: Univerza v Ljubljani, Filozofska fakulteta. DOI: https://doi.org/10.4312/9789610603979

Kyriacou, C. (2001). Teacher stress: Directions for future research. Educational review, 53(1), 27-35.

Ljubetić, M., \& Zadro, S. (2009). Samoprocjena kompetentnosti učitelja za pedagoški rad s roditeljima. Školski vjesnik, 58(1), 33-48.

Maslach, C., \& Jackson, S. E. (1986). Maslach Burnout Inventory, 2nd Edn, Palo Alto, CA: Consulting Psychologists Press.

Maleš, D. (2015). Partnerstvom obitelji i škole do uspješnog odgojno-obrazovnog rada. In S. Opić, V. Bilić \& M. Jurčić (Eds.), Odgoj u školi (pp. 45-74). Zagreb: Učiteljski fakultet Sveučilišta u Zagrebu.

Maphalala, M. C. (2014). The manifestation of occupational stress in the teaching profession: The unheeded voices of teachers. Mediterranean Journal of Social Sciences, 5(1), 77. DOI:10.5901/MJSS.2014.V5N1P77

Matijević, M. (2000). Učiti po dogovoru: uvod u tehnologiju obrazovanja odraslih. Zagreb: Birotehnika.

Miljković, D., Đuranović, M., \& Vidić, T. (2019). Odgoj i obrazovanje - iz teorije u praksu. Zagreb: IEP-D2; UFZG.

Olčar, D. (2015). Teachers' Life Goals and Well-Being: Mediating Role of Basic Psychological Needs and Flow (Unpublished doctoral dissertation). University of Zagreb, Zagreb, Croatia.

Rasmitadila, R., Aliyyah, R. R., Rachmadtullah, R., Samsudin, A., Syaodih, E., Nurtanto, M., \& Suryanti Tambunan, A. R. (2020). The Perceptions of Primary School Teachers of Online Learning during the COVID-19 Pandemic Period: A Case Study in Indonesia. Journal of Ethnic and Cultural Studies, 7(2), 90-109. http://dx.doi.org/ 10.29333/ejecs/388

Ravalier, J.M., \& Walsh, J. (2018). Working conditions and stress in the English education system. Occupational Medicine, 68(2), 129-134. DOI: 10.1093/occmed/kqy017

Sablić, M., Klasnić, I., \& Škugor, A. (2020). Učitelj u izolaciji: izazovi novog normalnog. In V. Strugar, A. Kolak \& I. Markić (Eds.), Školovanje od kuće i nastava na daljinu u vrijeme HR-COVID-19 (pp. 87-107). Zagreb-Bjelovar: Hrvatska akademija znanosti i umjetnosti Zavod za znanstvenoistraživački i umjetnički rad u Bjelovaru; Hrvatsko pedagogijsko društvo; Element.

Schaufeli, W.B., \& Taris, T.W. (2014). A critical review of the job demands-resources model: Implications for improving work and health. In G.F.Bauer \& O. Hämmig (Eds.), Bridging occupational, organizational and public health (pp. 43-68). Springer, Dordrecht. DOI:10.1007/978-94-007-5640-3_4

Sokal, L.J., Eblie Trudel, L.G., \& Babb, J.C. (2020). Supporting Teachers in Times of Change: The Job Demands- Resources Model and Teacher Burnout During the COVID-19 Pandemic. International Journal of Contemporary Education, 3(2), 67-74. DOI:10.11114/ijce.v3i2.4931

Zrilić, S., \& Marin, K. (2019). Kompetencije u suvremenoj školi - potrebe prakse iz perspektive učitelja. Školski vjesnik, 68(2), 389-400. Retrieved from https://hrcak.srce.hr/234953 